\title{
Fourteen years of palaeolimnological research of a past industrial polluted lake (L. Orta, Northern Italy): an overview
}

\author{
Piero GUILIZZONI*, Andrea LAMI, Aldo MARCHETTO, Peter G. APPLEBY ${ }^{1)}$ and Francesca ALVISI ${ }^{2)}$ \\ CNR Istituto Italiano di Idrobiologia, Largo Tonolli 50, I 28922 Verbania Pallanza, Italy \\ ${ }^{1)}$ Dept. of Applied Mathematics and Theoretical Physics, University of Liverpool, P.O. Box 147, Liverpool L69 3BX, U.K. \\ ${ }^{2)}$ CNR Istituto per la Geologia Marina, Via P. Gobetti 101, I 40129 Bologna, Italy \\ *e-mail corresponding author: p.guilizzoni@iii.to.cnr.it
}

\begin{abstract}
The first sediment core analyses were carried out in 1958, but it is only from 1985 onward that a modern palaeolimnological approach was applied to the study of Lake Orta, a large and deep lake in North Italy, heavily polluted by ammonia and copper for about 50 and 30 years, respectively. Thus, we summarise those studies from a variety of sediment cores, collected in different years and sites, using both published and unpublished data. Changes in algal pigments (mainly chlorophyll derivatives, total and single carotenoids), inorganic geochemistry, especially heavy metals (e.g. Cu), diatoms, Cladocera, and thecamoebians were studied and related to the stressed environment. The whole picture reveals a close relationship between modifications in algal biomass, density, taxonomic composition and organisms size on the one hand, and water chemistry changes on the other hand. Long-term history of this lake over 7-8 centuries, including invertebrate and terrestrial vegetation dynamics (pollen stratigraphy), reveals close relationship with natural (climate) and anthropogenic forces.
\end{abstract}

Key words: palaeolimnology, sediments, fossil remains, pigments, geochemistry, pollen, pollution

\section{INTRODUCTION}

Lake Orta is one of the most intensively studied freshwater environments in the world and the present collection of papers is only the last of a long series of publications (see, for example, papers quoted in Bonacina \& Bonomi 1984; Bonacina et al. 1990; Calderoni $\&$ de Bernardi 1992). Long-term limnological data dating back to the beginning of 1900 has shown in great detail the dramatic history of its pollution by heavy metals and ammonium sulphate, events that have made this large, deep and important Italian water resource internationally renowned among limnologists.

Historical data concerning Lake Orta have also been obtained using palaeolimnological techniques. This approach was essential for determining the record of the pre-industrial centuries, but has also been invaluable for some recent periods (e.g., 1930-1950) in which field data were lacking or (e.g., phytoplankton) very scarce and incomplete. These gaps were first investigated by Corbella et al. (1958) in their pioneering work on sediment cores from Orta in which the historical record of the lake was reconstructed from geochemical records (e.g., $\mathrm{Cu}$, organic content), sub-fossil diatom remains and plant pigments in the sediments. The results of this palaeolimnological study were in good agreement with the limnological data and showed clearly the strong impact of the heavy pollution by copper and ammonia on the lake chemistry and biota.

Further studies have subsequently been carried out on a number of sediment cores collected since 1978
(Tab. 1). The main objectives were: (1) to determine a detailed history of primary production (Adams et al. 1978; Guilizzoni et al. 1992, 1993); (2) to reconstruct changes in algal assemblages using species or group specific carotenoids (Guilizzoni \& Lami 1988, 1990), and (3) to estimate the natural variability and impact of pollution on diatom, Cladocera (Ruggiu et al. 1998; Manca \& Comoli 1995) and Oligochaete communities (Bonacina et al. 1986). Finally, a recently a study was published on the effects of pollutants on body size of three communities from different kingdoms and trophic levels (diatoms, Cladocera and thecamoebians; Cattaneo et al. 1998). Studies of mineralogy, lithology, pollen, magnetic properties (Alvisi 1993; Frignani et al. 1995; Alvisi et al. 1996) and sediment contamination by heavy metals (Provini \& Gaggino 1985; Baudo et al. 1989; Guilizzoni \& Lami 1990; Rossi et al. 1998), were also carried out.

The objective of the present paper is to present a general review of the main findings and results of these earlier studies (see Tabs 1-3 for a summary), and also to report new data on sedimentation rates, geochemistry, mineralogy, pollen and pigments for a more recent core collected in 1992.

\section{SITE HISTORY}

Lake Orta is a large deep subalpine lake in Northern Italy situated between $45^{\circ} 46^{\prime}-45^{\circ} 52^{\prime} \mathrm{N}$ and $8^{\circ} 23^{\prime}-$ $8^{\circ} 26^{\prime} \mathrm{W}$. It has a surface area of $18.5 \mathrm{~km}^{2}$, a maximum depth of $143 \mathrm{~m}$, a mean depth of $71 \mathrm{~m}$ and a volume of $1.3 \mathrm{~km}^{3}$ (Fig. 1). The catchment area consists primarily 
Tab. 1. Core inventory for Lake Orta since the first study in 1956.

\begin{tabular}{|c|c|c|c|c|c|}
\hline Core & Site & Date & Coring depth & Corer & Reference \\
\hline OR-56/1 & Buccione & 1956 & $20 \mathrm{~m}$ & Moore & Corbella et al. 1958 \\
\hline OR-56/2 & Buccione & 1956 & $35 \mathrm{~m}$ & Moore & Corbella et al. 1958 \\
\hline OR-82/3 & Buccione & 1982 & n.a. & Jenkin & Provini \& Gaggino 1985 \\
\hline OR-85 & Buccione & 1985 & $30 \mathrm{~m}$ & Jenkin & Ruggiu et al. 1998 \\
\hline OR1 & Buccione & 1990 & $30 \mathrm{~m}$ & Mackereth & Alvisi 1993 ;Frignani et al. 1995 \\
\hline OR-94 & Buccione & 1994 & $30 \mathrm{~m}$ & Limnos & Cattaneo et al. 1998; Manca \& Comoli 1995 \\
\hline OR-95 & Buccione & 1995 & $10 \mathrm{~m}$ & Scuba diving & Rossi et al. 1998 \\
\hline OR-56/4 & Pettenasco & 1956 & $122 \mathrm{~m}$ & Moore & Corbella et al. 1958 \\
\hline OR-78 & Pettenasco & 1978 & $100 \mathrm{~m}$ & Freeze corer & Adams et al. 1978 \\
\hline OR-85/B & Pettenasco & 1985 & $\sim 100 \mathrm{~m}$ & Jenkin & Bonacina et al. 1986 \\
\hline OR-86 & Pettenasco & 1986 & $120 \mathrm{~m}$ & Jenkin & Guilizzoni \& Lami 1988 \\
\hline OR-92 & Pettenasco & 1992 & $120 \mathrm{~m}$ & gravity & this paper \\
\hline
\end{tabular}

Tab. 2. Major changes in sediment profiles (cm): $\left({ }^{*}{ }^{210} \mathrm{~Pb}\right.$ dating (this paper), $\left({ }^{* *}\right) \mathrm{H}$. Muntau (unpublished data).

\begin{tabular}{|c|c|c|c|c|c|c|c|}
\hline $\begin{array}{l}\text { Event } \\
\text { Date }\end{array}$ & $\begin{array}{c}\text { Floods } \\
1963,1965\end{array}$ & pigments peak & $\begin{array}{l}\text { Cu peak } \\
1958-' 60\end{array}$ & $\begin{array}{l}\text { biota change } \\
1928-' 30\end{array}$ & $\begin{array}{c}\text { lithology change } \\
1928-' 30\end{array}$ & $\begin{array}{l}\text { LOI increase } \\
1928-30\end{array}$ & $\begin{array}{l}\text { Cu onset } \\
1928-' 30\end{array}$ \\
\hline \multicolumn{8}{|l|}{ Core } \\
\hline OR-56/1 & & & & 4 & & & 4 \\
\hline OR-56/2 & & & & 4 & & & 4 \\
\hline OR-78 & & $8-10$ & & & 10 & 10 & \\
\hline OR-82/3 & & & $6-7$ & & & & 9 \\
\hline OR-85 & $4-5$ & & & 9 & & $10-11$ & \\
\hline OR1 & $5 \mathrm{~cm}(*)$ & & $5.5(*)$ & & 10 & 10 & $8(*)$ \\
\hline OR-94 & & & & 7 & & 7 & \\
\hline OR-95 & & & $6-8$ & & & & \\
\hline OR-56/4 & & & & 5 & & & 6 \\
\hline \multicolumn{8}{|l|}{ OR-85/B } \\
\hline OR-86 & $6-7$ & $9-10$ & 11 & & & 12 & 13 \\
\hline OR-92 & $5-8$ & $10-11$ & $11(* *)$ & 13 & 12.5 & 12.5 & 12.5 \\
\hline
\end{tabular}

Tab. 3. Mean sedimentation rates $\left(\mathrm{cm} \mathrm{y}^{-1}\right)$ during the last 60 years at two coring sites, based on an historical flood event and on chemical and biological markers (cf. Tabs $1 \& 2$ ).

\begin{tabular}{|c|c|c|c|c|c|c|}
\hline Core & since 1964 & based on & since 1959 & based on & since 1929 & based on \\
\hline & & & at Buccione & & & \\
\hline OR-56/1 & & & & & 0.15 & $\mathrm{Cu} \&$ biota \\
\hline OR-56/2 & & & & & 0.15 & $\mathrm{Cu} \&$ biota \\
\hline \multirow[t]{2}{*}{ OR- $82 / 3$} & & & 0.28 & $\mathrm{Cu}$ & 0.17 & $\mathrm{Cu} \&$ biota \\
\hline & 011 & flood & 0.24 & ${ }^{137} \mathrm{Cs}$ & 0.19 & LOI \\
\hline OR-85 & & & & & $\begin{array}{l}0.19 \\
0.16\end{array}$ & $\begin{array}{l}\text { LU1 } \\
\text { biota }\end{array}$ \\
\hline \multirow[t]{2}{*}{ OR1 } & 0.14 & ${ }^{210} \mathrm{~Pb}$ & 0.21 & ${ }^{210} \mathrm{~Pb}$ & 0.13 & $210 \mathrm{~Pb}$ \\
\hline & & & & & 0.16 & biota \& LOI \\
\hline OR-94 & & & & & 0.11 & biota \& LOI \\
\hline \multirow[t]{2}{*}{ OR-95 } & & & 0.19 & $\mathrm{Cu}$ & 0.09 & $\mathrm{Cu}$ \\
\hline & & & at Pettenasco & & & \\
\hline \multirow[t]{2}{*}{ OR-56/3 } & & & & & 0.22 & biota \\
\hline & & & & & 0.19 & LOI \\
\hline OR-78 & & & $\leq 0.20$ & ${ }^{137} \mathrm{Cs}$ & 0.20 & LOI \& pigments \\
\hline OR-85/B & & & & & 0.21 & biota \\
\hline \multirow[t]{2}{*}{ OR- 86} & 0.22 & flood & 0.41 & $\mathrm{Cu}$ & 0.21 & LOI \\
\hline & & & & & 0.23 & $\mathrm{Cu}$ \\
\hline OR-92 & 0.15 & flood & 0.33 & $\mathrm{Cu}$ & 0.20 & $\mathrm{Cu} \& \mathrm{LOI}$ \\
\hline
\end{tabular}

of acid rocks (granite, gneiss) and especially on the western side is extensively covered by woods of Castanea sativa, Quercus spp., Juglans regia and Fagus silvatica. Further details are given in Frignani et al. (1995) (site description), Calderoni et al. (1999) (hydrochem- istry), Alvisi (1993) (regional physiography and geology) and other papers in this issue.

Water quality deteriorated significantly after 1926 when a rayon factory (Fig. 1) began to discharge large amounts of copper $\left(80 \mathrm{t} \mathrm{y}^{-1}\right)$ and ammonium sulphate 


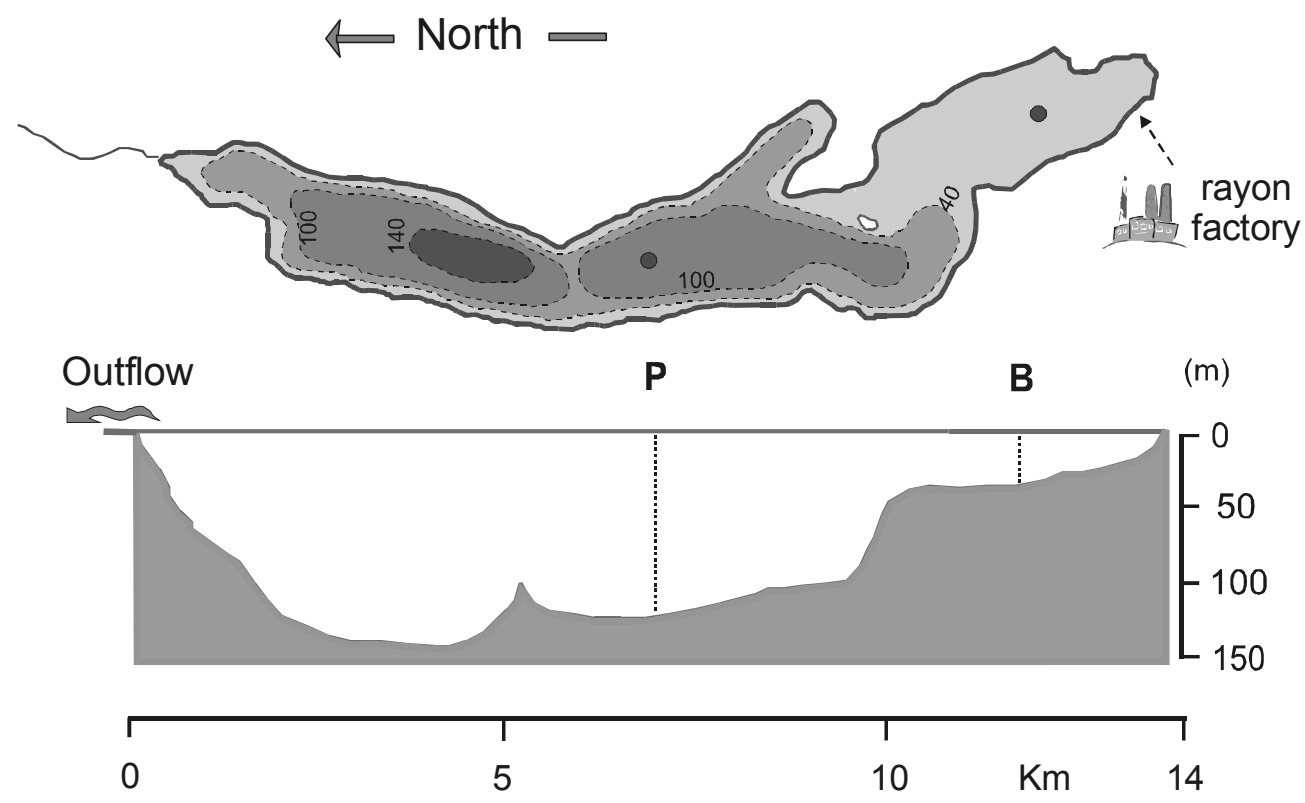

Fig. 1. Morphometry and longitudinal profile of Lake Orta: $\mathbf{P}$ (Pettenasco) and B (Buccione) are the coring sites. The location of the rayon factory responsible of the lake pollution for $c a 50$ years (1927-1980) is also indicated.

Tab. 4. ${ }^{210} \mathrm{~Pb}$ chronology for core OR1 (Buccione) of Lake Orta.

\begin{tabular}{lcccccc}
\hline Depth cm & $\begin{array}{c}\text { Dry Mass } \\
\left(\mathrm{g} \mathrm{cm}^{-2}\right)\end{array}$ & Date AD & $\begin{array}{c}\text { Age } \\
(\mathrm{y})\end{array}$ & $\begin{array}{c}\text { Sedim. Rate } \\
\left(\mathrm{g} \mathrm{cm}^{-2} \mathrm{y}^{-1}\right)\end{array}$ & $\begin{array}{c}\text { Sedim. Rate } \\
\left(\mathrm{cm} \mathrm{y}^{-1}\right)\end{array}$ & $\begin{array}{c} \pm \\
(\%)\end{array}$ \\
\hline 0.00 & 0.00 & 1990 & 0 & 0.038 & 0.27 & 4.9 \\
1.00 & 0.09 & 1988 & $2 \pm 2$ & 0.034 & 0.23 & 5.2 \\
2.00 & 0.25 & 1982 & $8 \pm 2$ & 0.024 & 0.19 & 5.5 \\
3.00 & 0.40 & 1976 & $14 \pm 2$ & 0.019 & 0.16 & 5.8 \\
4.00 & 0.56 & 1971 & $19 \pm 2$ & 0.015 & 0.12 & 6.2 \\
5.00 & 0.72 & 1965 & $25 \pm 2$ & 0.015 & 0.093 & 7.8 \\
6.00 & 0.89 & 1952 & $38 \pm 2$ & 0.015 & 0.093 & 7.8 \\
7.00 & 1.06 & 1941 & $49 \pm 3$ & 0.015 & 0.093 & 7.8 \\
8.00 & 1.23 & 1930 & $60 \pm 3$ & 0.015 & 0.093 & 7.8 \\
9.00 & 1.39 & 1919 & $71 \pm 4$ & 0.015 & 0.093 & 7.8 \\
10.00 & 1.55 & 1908 & $82 \pm 5$ & 0.015 & 0.093 & 7.8 \\
11.00 & 1.71 & 1891 & $93 \pm 6$ & 0.015 & 0.087 & $\sim 10$ \\
12.00 & 1.90 & 1885 & $105 \pm 8$ & 0.015 & 0.087 & $\sim 10$ \\
13.00 & 2.08 & 1873 & $117 \pm 10$ & 0.015 & 0.087 & $\sim 10$ \\
14.00 & 2.26 & 1861 & $129 \pm 12$ & 0.015 & 0.087 & $\sim 10$ \\
15.00 & 2.44 & 1849 & $141 \pm 14$ & 0.015 & 0.087 & $\sim 10$ \\
16.00 & 2.62 & 1837 & $153 \pm 16$ & 0.015 & 0.087 & $\sim 10$ \\
\hline
\end{tabular}

(max $3350 \mathrm{t} \mathrm{N}-\mathrm{NH}_{4} \mathrm{y}^{-1}$; Calderoni \& Mosello 1990) into the lake. By 1950 the naturally poorly buffered waters in the profundal layers had become progressively acid ( $\mathrm{pH} \mathrm{ca} 4$ ) and anoxic due to $\mathrm{NH}_{4}$ in-lake oxidation. Concentrations of toxic substances in effluents from the rayon factory were greatly reduced in $1958(\mathrm{Cu})$ and $1980\left(\mathrm{NH}_{4}\right)$, though a further source of pollution during the past 20-30 years has been from trace metals (e.g., $\mathrm{Cr}, \mathrm{Zn}, \mathrm{Ni}, \mathrm{Zn}$ ) in effluents from the many electroplating factories bordering the lake. In 1988 the lake was treated with lime (Calderoni et al. 1991) and since then has been progressively recovering its "stability" (Calderoni \& Tartari 2001).

\section{CHRONOLOGY AND SEDIMENT ACCUMULATION}

A sediment core from Lake Orta (OR1; cf. Tab. 1), collected in July 1990 from the Buccione Basin (Fig. 1), was measured non-destructively in the Liverpool University Environmental Radiometric Laboratory for ${ }^{210} \mathrm{~Pb},{ }^{226} \mathrm{Ra},{ }^{241} \mathrm{Am},{ }^{137} \mathrm{Cs}$ and ${ }^{134} \mathrm{Cs}$ by direct gamma assay using Ortec HPGE GWL series (Appleby et al. 1986; Appleby et al. 1992). The results of the radiometric analyses are given in table 4 and shown graphically in figures 2-4. Activity of the short-lived radiocaesium isotope ${ }^{134} \mathrm{Cs}$, which derives solely from fallout from the 
Chernobyl reactor accident, has been corrected for decay since $5^{\text {th }}$ May 1986.

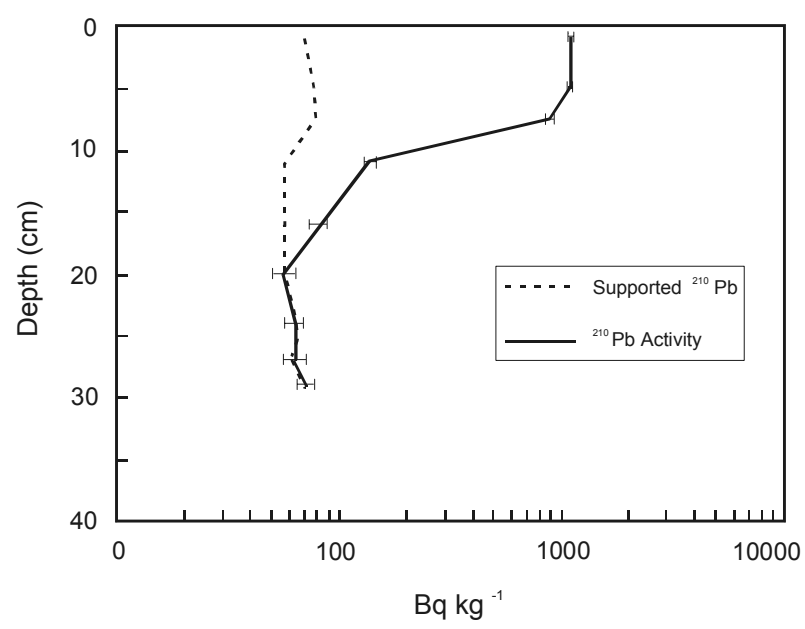

Fig. 2. Total and supported ${ }^{210} \mathrm{~Pb}$ stratigraphy in Lake Orta core OR1.

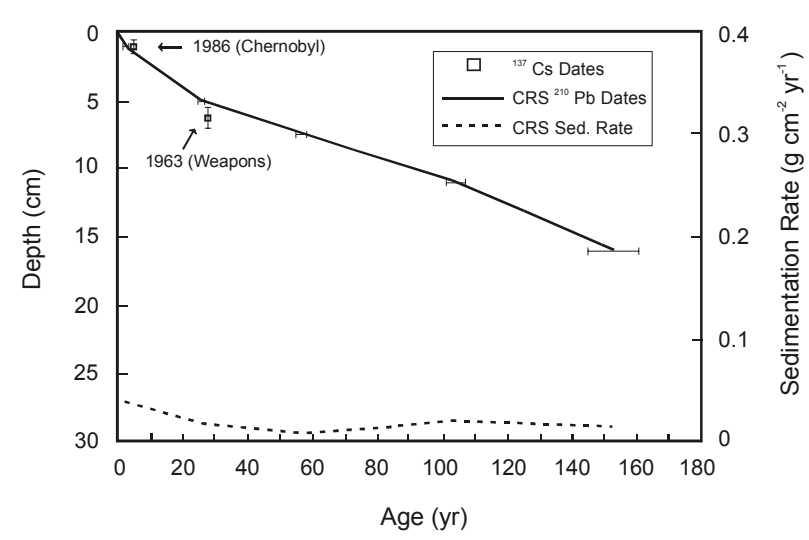

Fig. 3. Age-depth relationship and accumulation rate in Lake Orta core OR 1 as determined by ${ }^{210} \mathrm{~Pb}$ (Constant Rate of Supply model).

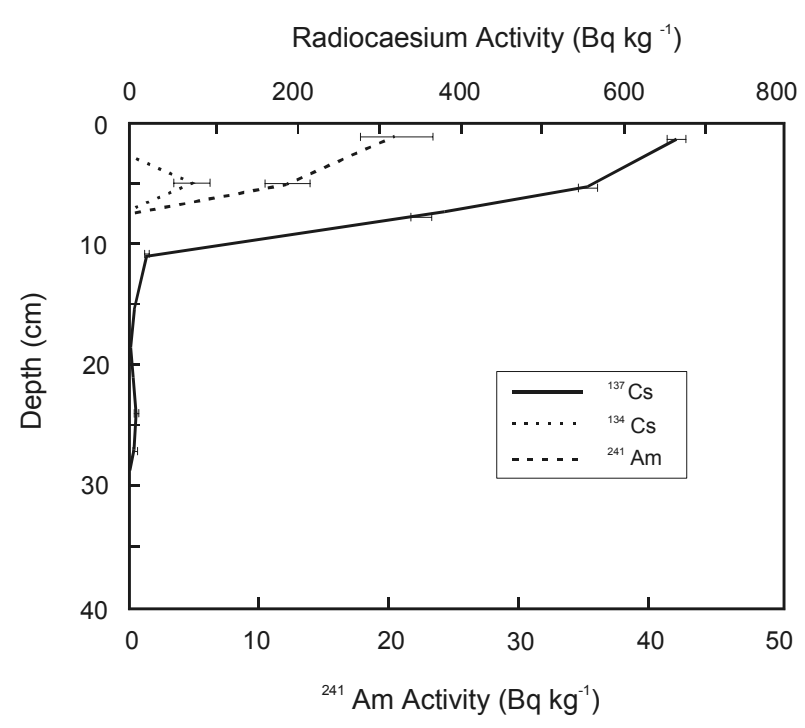

Fig. 4. Depth profiles of radiocaesium and ${ }^{241}$ Americium concentrations in Lake Orta core OR1.
Equilibrium between total ${ }^{210} \mathrm{~Pb}$ activity and the supporting ${ }^{226} \mathrm{Ra}$, corresponding to about 150 years of sediment accumulation, was reached at a depth of between $16-20 \mathrm{~cm}$. Unsupported ${ }^{210} \mathrm{~Pb}$ activity was virtually constant in the top $6 \mathrm{~cm}$ of the core but beneath this zone fell steeply following a more or less exponential relationship with depth.

The high ${ }^{137} \mathrm{Cs}$ and ${ }^{134} \mathrm{Cs}$ concentrations in the uppermost samples record deposition from the Chernobyl accident, and also confirm the integrity of the surficial sediment record. From the distribution of the Chernobyl fallout it is estimated that sediments from 1986 lie at a depth of not more than $2 \mathrm{~cm}$. It is evident from the ${ }^{134} \mathrm{Cs}$ record that Chernobyl ${ }^{137} \mathrm{Cs}$ has diffused down the sediment column to a depth of $c a 5-7 \mathrm{~cm}$. Using the ${ }^{134} \mathrm{Cs} /{ }^{137} \mathrm{Cs}$ ratio characteristic of Chernobyl fallout it was possible to partition the total ${ }^{137} \mathrm{Cs}$ activity into its Chernobyl and weapons fallout components and so reconstruct the weapons fallout ${ }^{137} \mathrm{Cs}$ record. The results of these calculations had large uncertainties, but nonetheless place the 1963 weapons fallout peak at a depth of between $5-7 \mathrm{~cm}$. This was supported by the presence of traces of ${ }^{241} \mathrm{Am}$ at $5 \mathrm{~cm}$ depth (Appleby et al. 1991). The weapons ${ }^{137} \mathrm{Cs}$ record has a small but significant secondary peak in activity at $23-28 \mathrm{~cm}$. Since this is well below the possible 1954 depth marking the onset of ${ }^{137} \mathrm{Cs}$ fallout the most likely cause is downwards transport of ${ }^{137} \mathrm{Cs}$ by pore water diffusion with preferential adsorption due to a change in mineralogy or sediment chemistry at these depths.

${ }^{210} \mathrm{~Pb}$ dates calculated using the CRS (Constant Rate of Supply) model (Appleby \& Oldfield 1978), shown in figure 3 , are in relatively good agreement with the radiocaesium dates, implying that the near uniform ${ }^{210} \mathrm{~Pb}$ activity in the surficial sediments is due to dilution of the constant atmospheric ${ }^{210} \mathrm{~Pb}$ flux by accelerating sedimentation. The alternative explanation of physical mixing is precluded by the decline in radiocaesium concentrations in the top $6 \mathrm{~cm}$ of the core. Further, use of a mixing model would give a date for the weapons fallout peak that is clearly too old (1927 AD).

The ${ }^{210} \mathrm{~Pb}$ dates for OR1, given in table 4, put 1930 at a depth of $8 \mathrm{~cm}, 1900$ at a depth of $10.5 \mathrm{~cm}$, and 1850 at a depth of $15 \mathrm{~cm}$. Prior to 1971 there appears to have been a more or less constant sedimentation rates of $0.015 \pm 0.002 \mathrm{~g} \mathrm{~cm}^{-2} \mathrm{y}^{-1}$ ( ca $\left.0.087 \mathrm{~cm} \mathrm{y}^{-1}\right)$. Changes since then have more than doubled this to a present day value of about $0.038 \mathrm{~g} \mathrm{~cm}^{-2} \mathrm{y}^{-1}$. The mean post-1963 sedimentation rate calculated from the ${ }^{137} \mathrm{Cs}$ dates is $0.033 \pm 0.006 \mathrm{~g} \mathrm{~cm}^{-2} \mathrm{y}^{-1}\left(0.22 \mathrm{~cm} \mathrm{y}^{-1}\right)$ compared to $0.029 \pm 0.003 \mathrm{~g} \mathrm{~cm}^{-2} \mathrm{y}^{-1}\left(0.20 \mathrm{~cm} \mathrm{y}^{-1}\right)$ by ${ }^{210} \mathrm{~Pb}$. These results compare quite well (especially for the last 40 years) with independent dating evidence from a number of cores from the Buccione basin using LOI data, pigments, biota assemblage changes and flood events (Tab. 3 ). Table 3 also shows that sedimentation rates in the Buccione Basin are lower than those in the deeper Pet- 


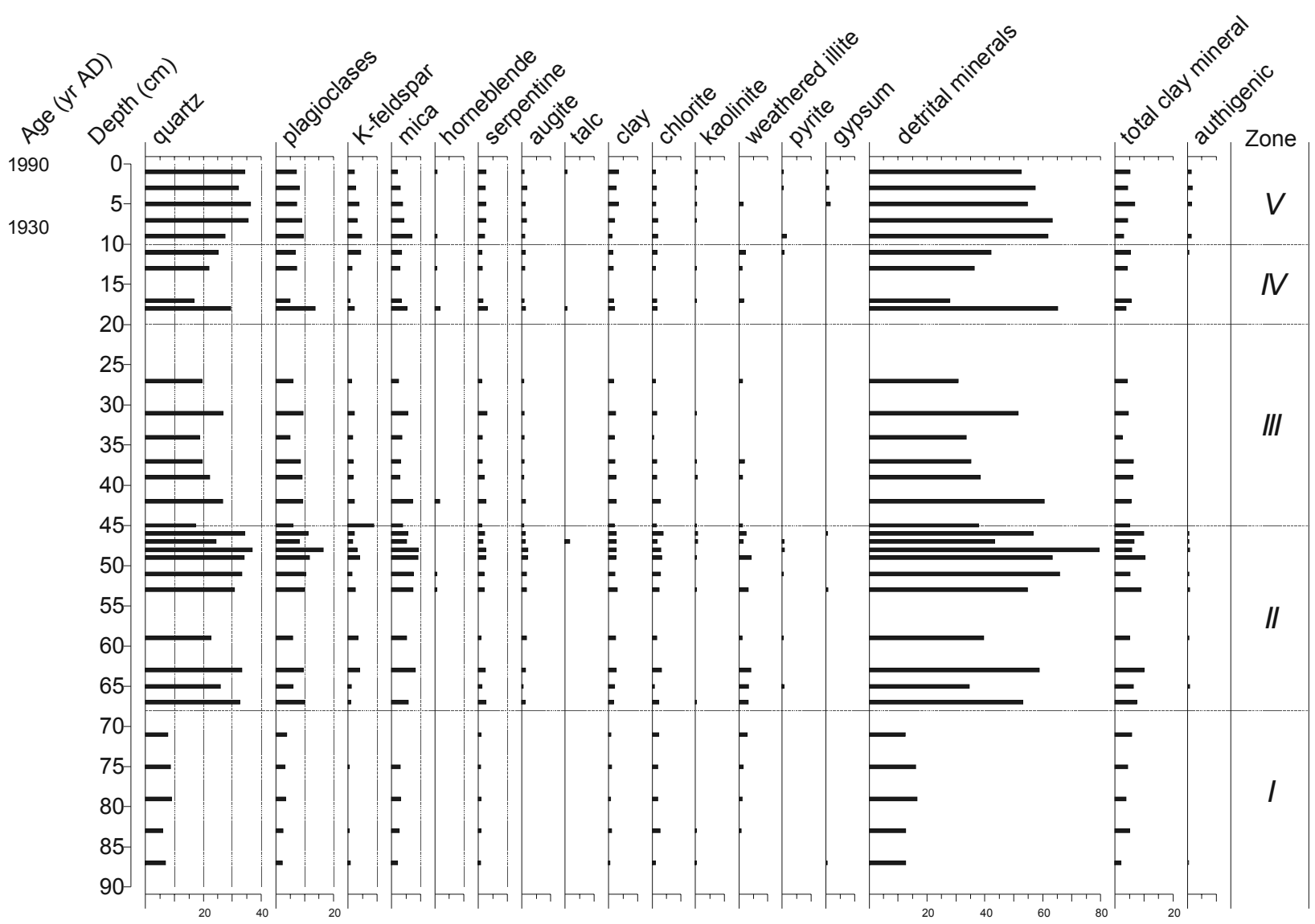

Fig. 5. Mineralogical composition (as absolute values of the heights of the measured peaks) of Lake Orta core OR1. Zone I-V are also indicated.

tenasco basin (e.g., core OR-92, results for which based on pigment analysis, LOI and other parameters are presented below for the first time).

\section{CORE DESCRIPTION}

The lithology of core OR1 can be subdivided in two main units. The deeper sediments (from the base of the core up to about $15 \mathrm{~cm}$ ) were composed of a rather homogeneous brown to light-grey clay ( $\mathrm{ca}$ 60\%), silt $(37 \%)$ and sand $(<1 \%)$ (Alvisi et al. 1996). Above this was a layer of black fine grained gyttja. Other cores had a similar structure, with the thickness of the upper layer varying from $10-15 \mathrm{~cm}$ depending on core location. A number of lighter and darker bands are present throughout (Frignani et al. 1995), though these are not annual laminations. As in most sub-alpine lakes (e.g., Maggiore, Mergozzo; Guilizzoni \& Lami 1992) with large drainage basins, the pelagic lacustrine sedimentation at the maximum depth is often interrupted by turbidites (Guilizzoni \& Lami 1990). Between 5 and $8 \mathrm{~cm}$ there are a number of turbidites that have been related to historical flood events in 1963 and 1965 (Ambrosetti et al. 1994). In the shallower Buccione Basin (water depth 30 $\mathrm{m}$ ) the sediments are more homogeneous, although with lower sedimentation rates than in the deeper Pettenasco
Basin (cf. Alvisi 1993; Tab. 3). Loss on ignition is rather high ranging from $\mathrm{ca} 10 \% \mathrm{~d} . \mathrm{w}$. to $40 \%$ during 1960-1990. Carbonate concentrations are low (ca 7\%).

\section{DATA ANALYSIS}

The sediment sequence in core OR1 was split into 5 broadly matching zones based on the magnetic susceptibility (Alvisi et al. 1996) and pollen results (see below; Alvisi 1993). Zone I extended from $88-\mathrm{c} .67 \mathrm{~cm}$, zone II from c.67-45 cm, zone III from $45-c a 20 \mathrm{~cm}$, zone IV from $20-10 \mathrm{~cm}$, and zone $\mathrm{V}$ from $10-0 \mathrm{~cm}$.

Core OR-92 was zoned using CONISS (CONstrained Incremental Sum of Squares) cluster analysis of the geochemical and pigments profiles with square root transformation of the original data to optimise the signal to noise ratio. In this scheme zone I extends from 70-20 $\mathrm{cm}$, zone II from $20-9 \mathrm{~cm}$, zone III from $9-4.5 \mathrm{~cm}$, zone IV from $4.5-1.75$, and zone V from $1.75-0 \mathrm{~cm}$. The sequence of pollen grains was divided on a preliminary and subjective basis into five broad biostratigraphic zones which match reasonable well to the CONISS plot for the sequence.

Comparing the different phases of the lake development based on this analysis (cf. Figs 5 and 6 below) it appears that the OR-92 zone I corresponds to OR1 
zones II and III; OR-92 zone II corresponds to OR1 zone IV; OR-92 zones III, IV and V correspond to OR1 zone $\mathrm{V}$.

\section{MINERALOGY}

Mineralogical analysis of the core sediments can be used to determine the nature and amount of the sedimentary input eroded from the drainage basin as opposed to that derived from physical-chemical processes within the lake. Bulk dry sediment and the clay fraction from core OR1 was analysed by means of an X-ray diffractometer (see Alvisi 1993 for methological details). Due to analytical problems, in zone I $(88-67 \mathrm{~cm})$ only the clay fraction was analysed. In figure 5, the mineralogical data for this zone refer only to that fraction whereas for the other zones the data refer to the bulk sediment.

The results are based on the heights of selected peaks of reflection of the main mineral phases (Tucker 1988). Derived parameters that are more sensitive to environmental changes (e.g., the illite crystallinity index; Chamley 1989) are also discussed below. The inorganic fraction, calculated as the residue in percentage of the dry weight after loss on ignition at $550{ }^{\circ} \mathrm{C}$ (ash content), is about $88 \%$ d.w. in the lower zones, I to IV, with only two exceptions at around 67 (85-86\% d.w.) and $45(91-92 \%$ d.w.) cm, and decreases to $75 \%$ in the uppermost zone $\mathrm{V}$.

The mineralogical composition of the Lake Orta shows two main phases of lake development (Fig. 5): the first phase, from the core bottom to $10 \mathrm{~cm}$ depth (spanning zones I-IV), reflects the meso-oligotrophic condition typical of other Italian sub-alpine deep lakes (Guilizzoni et al. 1983); the second, from $10 \mathrm{~cm}$ to the top of the core (zone V), is marked by sharp variations in many parameters clearly related to the strong chemical modifications in both the water column and sediments compartments that occurred during the main period of pollution.

Each of the zones within these two main phases is characterised by a number of mineralogical features based on changes in the quality and amount of sedimentary input to the lake bottom.

Zone $1(88-67 \mathrm{~cm})$. Here it is possible to observe few changes in the composition of the sedimentary input to the lake with a substantial stability of the accumulation rates as indicated by the susceptibility curve. The clay fraction shows the presence of kaolinite, the absence of degraded illite even with a high mica content, and a slight upward increase of detritic phases such as quartz and plagioclases. The crystallinity index of the total illite does not show any changes. However, the index of micas and degraded illite taken separately show a different behaviour. At the bottom of the profile the micas seem to be not degraded, but then the crystallinity of the micas decreases and the degraded illite begins to accumulate, probably favoured by an increase of the hydro- logical activity in the drainage area and increased erosion. The further increase of the illite degradation and the contemporary increase of the crystallinity index suggest an input of both weathered and unweathered material. All these features suggest a possible climatic amelioration from cooler and wetter to increasing warmer conditions from the bottom to around $75 \mathrm{~cm}$ depth of the core and/or an opening of the canopy with a consequent exposition of soils and rocks to weathering. In fact, the first increase of degraded illite input followed by the increase of primary micas could be due to the deeper erosion of the exposed areas with a consequent transport to the lake of both mineralogical components without any further chemical weathering. In the second part of this zone the detritic phases seem to decrease while the degraded illite still increase at the expenses of micas which disappear, and the organic fraction increase slightly around $67 \mathrm{~cm}$. These features suggest a decrease of deep erosion and a shift toward more organic sediments probably due to a recovery of the vegetation over the exposed areas possibly favoured by increased wetter conditions as shown by the pollen assemblage.

Zone II $(67-45 \mathrm{~cm})$. The dominance of detritic phases such as quartz, micas, augite and degraded illite (and the increase of the magnetic susceptibility values), average values of which are higher than in the other zones, points to an increase in the inorganic fraction sedimentation rate. Two major phases of deep erosion of unweathered material from the slopes are evident: the first one around $65 \mathrm{~cm}$ and then, after a period of relatively constant erosion rate, a second starting from 52 to 45 $\mathrm{cm}$. The pollen diagram shows that these increases are mainly the result of disturbances on the lake shores and slopes, linked to agricultural purposes. The land management changes seem to take place inside the drainage basin of the lake, its effects being recorded very rapidly in the lake sedimentary column.

Zone III $(45-20 \mathrm{~cm})$. The rather constant concentrations of organic matter, the decrease of the concentrations of the major indicator elements of erosion, and the uniform mineralogical composition point out a period of decreasing sedimentation rates. The ratio between organic and inorganic components remain unchanged during this interval. The susceptibility curve shows an initial decrease up to $35 \mathrm{~cm}$, followed by quite constant values similar to those preceding the peak at $45 \mathrm{~cm}$ depth. However, a slight increase of phosphorus, sulphur and silica, showing a different behaviour with respect to the detrital elements, should be linked to the increase of their organic compounds and thus could represent an increased productivity of the lake. All these features suggest a partial recover of the vegetation leading to a new equilibrium between erosion and vegetation cover, but the mean sedimentation rates are still higher than those in with Zone I. 
Zone IV (20-10 cm). At the beginning of this short interval the mineralogical composition shows a sharp increase of detrital phases such as quartz, plagioclases and micas, followed by an important drop in the detrital fraction and again a new recovery upward. This feature suggests a short period of rapid input of sediment to the lake probably due to a localised disturbance on the lake shore such as excavation for building purposes.

Zone $V(10-0 \mathrm{~cm})$. The huge peak of the susceptibility curve and the general increase of almost all the geochemical and some mineralogical parameters at the beginning of this interval point out a strong modification of the lake environment probably leading to particular stressed physical-chemical conditions on the lake floor. Among the detrital phases only quartz show a clear increase, whereas the others seem to decrease slightly probably because of their instability, except quartz, in the new lake conditions. The clay fraction also increased together with pyrite and sulphur (gypsum) revealing a more reactive mineralogical environment with possible oxygen depletion on the bottom. The analysis of the surface sediments reveals very high concentrations of copper, chromium, sulphur and iron. These elements were probably precipitated into the sediments soon after the $\mathrm{pH}$ of the lake waters was increased by the recent liming treatment directed to improve the quality of the lake basin (AA.VV. 1990, Calderoni et al. 1991). All the other elements display higher concentrations and for some of them the causes are the same as those seen above. Also the increased concentrations of some elements such as $\mathrm{Mn}, \mathrm{Ca}, \mathrm{Mg}, \mathrm{Al}, \mathrm{Fe}$ and $\mathrm{Ni}$ at the core top (see below) could be the result of the composition of the calcium carbonate used for liming operations.

\section{GEOCHEMISTRY}

Major elements (Ca, Mg, Na, K, Si, Al, Fe, Mn, S) were sparsely measured on core OR1 (collected in 1990 in the Southern Basin, Tab. 1) (Alvisi 1993). Here we report on results from that and other studies (see below).

Major cations. Element such as calcium, magnesium sodium and potassium in lake sediments are primarily associated with allogenic clastic eroded material from catchment soils and rocks. In particular, $\mathrm{K}$ (1.6-2.6\% d.w.), $\mathrm{Na}(0.8-1.3 \%$ d.w.) and $\mathrm{Mg}(1.6-2.7 \%)$ are often used to detect past soil erosion rates (Engstrom \& Wright 1984). Period of higher erosion are shown from the profiles of these elements (e.g. 1963, 1965, Tab. 1; cf. Guilizzoni \& Lami 1990). Si (54-62\% d.w.) and Al (12-21\% d.w.) trends show opposite behaviour, whereas $\mathrm{Ca}$ does not fluctuate through time ( $c a 0.7 \%$ d.w.) except an increase during the early $1990 \mathrm{~s}$ (1.3\% d.w.) (Alvisi 1993).

$\mathrm{Fe}, \mathrm{Mn}$. These two elements are perhaps the most important for palaeolimnology although their profiles are often difficult to interpret. In fact, a number of inde- pendent environmental factors control the supply of Fe and $\mathrm{Mn}$ to the lake sediments (e.g. erosion, weathering from the rocks, soil composition). Mackereth (1966) was probably the first to clearly recognise that their different mobility can be used to infer palaeo-redox conditions.

In Lake Orta the profile of Fe concentration shows a regular decreasing trend from $8 \% \mathrm{~d} . \mathrm{w}$. at the beginning of 1900 to $c a 5 \%$ at the end of the $80 \mathrm{~s}$. Mn decreases instead sharply from ca1950 (from $1000 \mathrm{ppm}$ to 250 ppm) (Guilizzoni \& Lami 1990; Muntau, unpublished data). These metals undergo resuspension and migration when sediment-water interface becomes reduced through oxygen depletion. The $\mathrm{Fe} / \mathrm{Mn}$ ratio increase steadily from 1960 (in coincidence with the increase oxygen hypolimnetic deficit) to the late 1980s (Guilizzoni \& Lami 1990).

Sulphur. Before 1920-30 this element has a mean concentration of $c a 0.20 \% \mathrm{~d} . \mathrm{w}$. Then it increases to a maximum (3\% d.w.) in the early 1990 s. There is a general agreement between this profile, the carbonaceous particles (Fig. 6) and magnetic curves (Alvisi 1993; Frignani et al. 1995) that may reflect a major increase in the atmospheric contamination by fuel combustion. In addition, there are many evidences from the Fe and $\mathrm{Mn}$ levels and the evolution of trophic and oxygen concentration (Calderoni \& Tartari 2001), that the enhanced S accumulation in the topmost $c a 15-10 \mathrm{~cm}$ of the core could be also related to the precipitation of ferrous sulphide which gives to the mud the characteristic black colour.

Nutrients. The concentrations of organic carbon and organic nitrogen exhibit a marked, progressive increase upward across the 1920 horizon (C: from $\mathrm{ca} 4 \%$ d.w. to $20 \%$; N: from $0.4 \%$ to $2.4 \%$ d.w.; Guilizzoni \& Lami 1990). These elements are accumulated in high quantities between 1930 and 1950: accumulation rates and concentrations increased from 70 (4\% d.w.) and $10 \mathrm{~g} \mathrm{~m}^{2}$ $\mathrm{y}^{-1}(0.4 \%$ d.w. $)$ to 170 (10\% d.w.) and $20 \mathrm{~g} \mathrm{~m}^{2} \mathrm{y}^{-1}(1.4 \%$ d.w.), respectively (Guilizzoni \& Lami 1990).

The C:N ratio indicates a prevailing lacustrine contribution of organic matter (values around or below 10; Guilizzoni \& Lami 1990).

Also total phosphorus exhibits a similar marked increased during the last 50 years ranging from a baseline content of ca. $0.22 \%$ d.w. to $c a 1 \%$ d.w. Taking into account all the pollution history in Lake Orta, variation in $\mathrm{P}$ retention which is controlled by factors such as redox potential, Fe chemistry, $\mathrm{pH}$ (Mitchell et al. 1990) - is in this lake probably more important than changes in $\mathrm{P}$ loading.

Other metals. Since 1958 many analyses of metals (particularly $\mathrm{Cu}$ ) were performed in sediment cores of Lake Orta (e.g., Provini \& Gaggino 1985; Guilizzoni \& Lami 1990; Alvisi 1993; Muntau et al. unpublished data) and the paper by Baudo \& Beltrami (2001) will give an ac- 


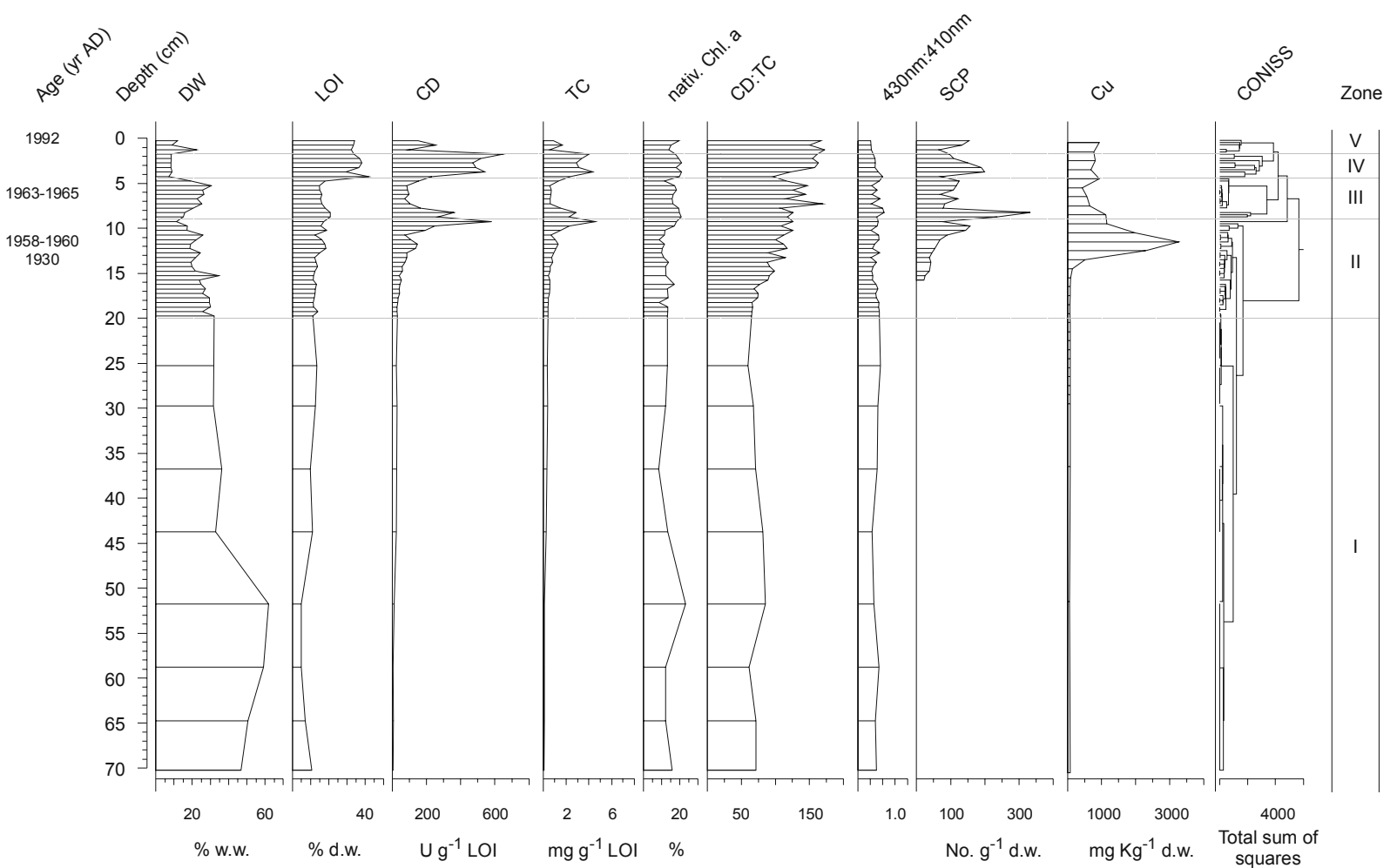

Fig. 6. Lake Orta, core OR-92. Selected physical and geochemical parameters. DW = dry mass; LOI $=$ Loss-on-ignition; $C D=$ Chlorophyll derivatives (U: absorbance units); $\mathrm{TC}=$ total carotenoids; Nativ. $\mathrm{Chl}-a$ and $430 \mathrm{~nm}: 410 \mathrm{~nm}$ ratio $=$ pigment degradation index; $\mathrm{SCP}=$ carbonaceous particles; $\mathrm{Cu}=$ copper. CONISS zones I-V are shown.

count of these studies. Here we report the $\mathrm{Cu}$ profile from core OR-92 (Fig. 6). All analyses clearly showed the many fold increase of the "baseline" heavy metal concentrations, (e.g., for $\mathrm{Cu}$ and $\mathrm{Cr}$ the natural concentrations are set at $c a 80,40$ ppm dry weight, respectively) a few years after the beginning of the rayon factory's discharge (Guilizzoni \& Lami 1990). In particular, the $\mathrm{Cu}$ sediment profiles parallel that on lake water at winter turnover (Cattaneo et al. 1998), showing a sharp decrease after 1958 (from ca 3300-5000 ppm d.w. to 1000 ppm d.w.; Fig. 6) when the discharge was drastically reduced. Similarly the $\mathrm{Cr}$ concentration shows a sharp increase from a baseline value of $c a 40 \mathrm{ppm}$ to a maximum at the end of the 1950s of $c a 4000 \mathrm{ppm}$. Because of the acidic bottom water conditions the concentrations of $\mathrm{Cu}, \mathrm{Cr}$ and $\mathrm{Al}$ in the water column reached very high values (around $100 \mathrm{\mu g} \mathrm{l}^{-1}$ ) during the early 60' and between 30 and $50 \mu \mathrm{g} \mathrm{l}^{-1}$ from mid 1970 to 1985 (Calderoni \& Mosello 1990; Calderoni \& Tartari 2001).

\section{ORGANIC MATTER AND FOSSIL PIGMENTS}

Water content is commonly highest at the top of the core ( $c$ a $80 \%$ ). Fluctuations are the result of turbidites as is the case for the sharp decrease in OR-92 at 5-8 cm (Tab. 2-3; floods events in 1963, 1965; Ambrosetti et al. 1994 ) which dilute all the organic compounds (see below).
Loss on ignition increases but with some fluctuations, from less than $6-10 \%$ d.w. in the oldest sediments to $c a 40 \%$ in the period 1965-1992 (core OR-92; Fig. 6), contemporarily to the establishment of eutrophication. However, as for the biological records, the significant increase of LOI begins around 1920-30 (values of $c a$ $20 \%$ d.w.), when senescent or dead organisms began to settle and accumulate because of pollution (Monti 1930).

An index of pigment preservation is given by the native chlorophyll, i.e. the proportion of chlorophyll not degraded to phaeopigments (Swain 1985). This index increases following the onset of lake pollution from a pre-1930 average of $c a 15 \%$ to $19-20 \%$ (Fig. 6). We postulate it is related to lake acidification and oxygen consumption through $\mathrm{NH}_{4}$ oxidation (Adams et al. 1978; Guilizzoni \& Lami 1990), which conditions inhibited microbial break-down of pigments (Guilizzoni \& Lami 1988).

In any pigment study the question "are the changes related to a better preservation or/and to the variations in pigment production ?" is of central importance (Leavitt 1993). In Lake Orta these two factors seems to operate jointly. First, the increases of chlorophyll preservation, as shown also by the $430 \mathrm{~nm}: 410 \mathrm{~nm}$ ratio (Guilizzoni et al. 1993), do not always match the rise in pigment (Fig. 6). Second, there is an earlier period of 


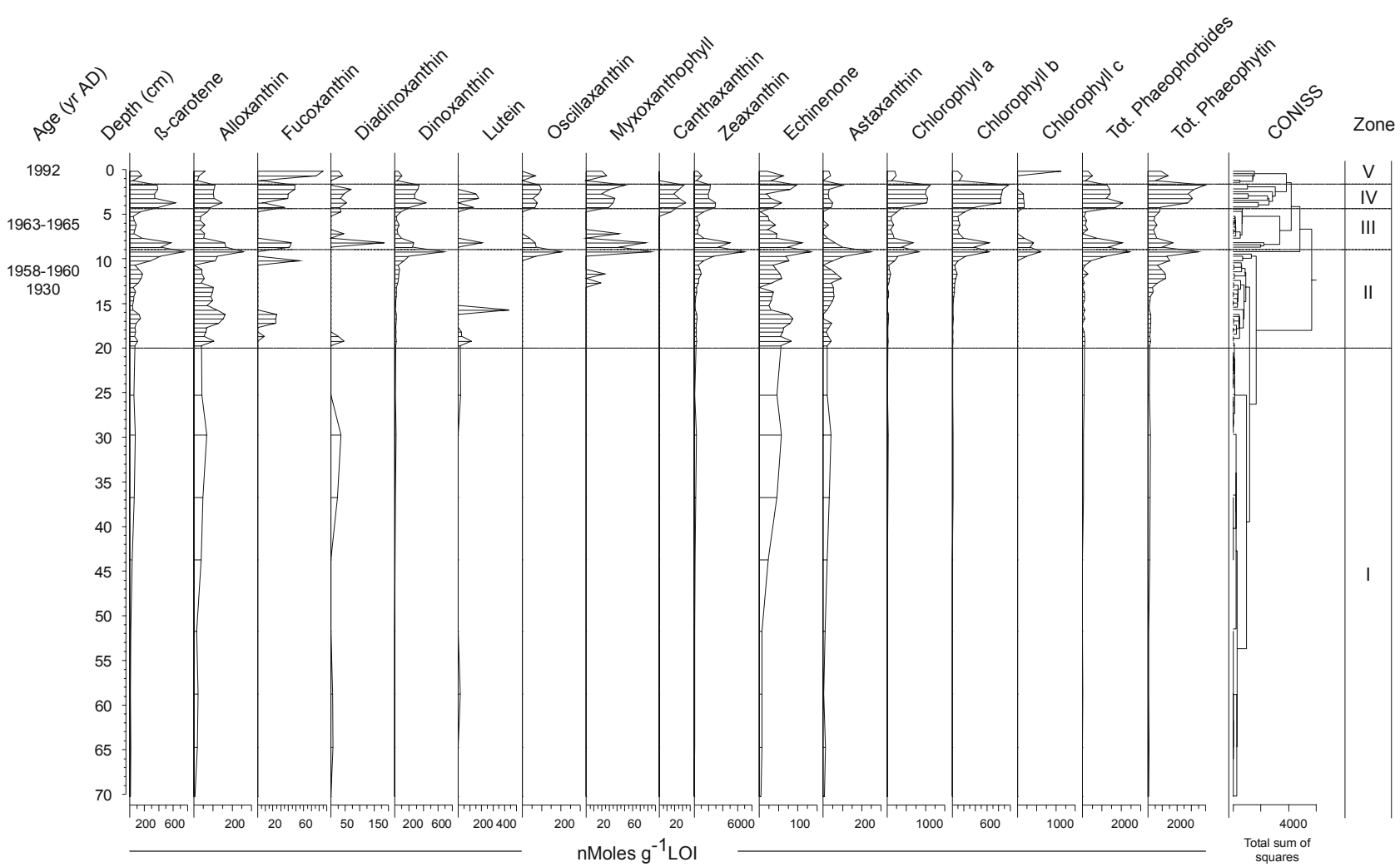

Fig. 7. Lake Orta, core OR-92. Algal fossil pigment concentration profiles. CONISS zones I-V are shown.

good preservation ( $\mathrm{ca} 52 \mathrm{~cm}$ ) during which pigment concentrations do not change.

Sedimentary $\mathrm{CD}$ and $\mathrm{TC}$ are detected in large amounts from 1930 onwards (Fig. 6). Their concentrations in the last $c a 60$ years are of the same magnitude as those detected in eutrophic lakes. Because of the toxic effect of $\mathrm{Cu}$ the post-1930 rise must have been caused mainly by a massive mortality of the phytoplankton community. The sharp decrease in all the pigment concentrations between 5 and $8 \mathrm{~cm}$ is due to large quantities of mineral deposition from soil erosion (floods of 1963 and 1965) that diluted the organic content of the samples. Notably low are total pigment concentrations in the pre-1900 periods. Moreover, the similarity in $\mathrm{CD}$ and $\mathrm{TC}$ curves indicates little allochthonous pigment input.

Analysis of single fossil carotenoids suggests that there have been dramatic changes in algal abundance and composition during the pollution decades (Zones IV and VI; Fig. 7). Concentrations of the chemically stable carotenoid $\beta$-carotene, indicative of total algal biomass, is variable in this period and shows little trend with depth: a slight rise in concentration is observed at $c a 30$ $\mathrm{cm}$. Here also diadinoxanthin (siliceous algae), alloxanthin (cryptophytes), echinenone (cyanobacteria) and astaxanthin/astacene show a peak. As a whole, the pre-1900 concentrations (zones I and II) are extremely low indicating a low productive environment. However, the increase in-lake productivity can be dated before the pollution onset (1930; zone III). The effect of early century industrialisation human disturbance in the Lake Orta catchment area is accordingly seen also from the carbonaceous particles (Fig. 6), $\mathrm{Pb}$ and $\mathrm{S}$ profiles (Alvisi 1993), as well as from pollen analysis.

Cyanobacteria are always present: they are particularly abundant from $50 \mathrm{~cm}$ upward. Colonial species are present during recent times only (zones III-VI), where very abundant is also zeaxanthin (carotenoid characteristic of green algae and cyanobacteria). Peaks of carotenoids are shown in zone IV and VI. These very variable pigment trends also support the evidence of an extremely biologically unstable ecosystem during the pollution phase.

\section{POLLEN}

For pollen analysis 11 sediment slices $1.5 \mathrm{~cm}$ thick were sampled every $8 \mathrm{~cm}$ in core OR1. After adding a known amount of Eucalyptus pollen grains, the samples were prepared following the procedure described by Faegri \& Iversen (1964) and modified by Alvisi (1993). A minimum of 500 terrestrial pollen grains have been counted for each sample. The grains have been identified on the basis of key tables (Faegri \& Iversen 1964; Moore \& Webb 1978), and reference material. The data have been elaborated and plotted with TILIA software package (Grimm 1991) with five categories of terrestrial and aquatic taxa: trees, shrubs, herbs, aquatic and spores. 


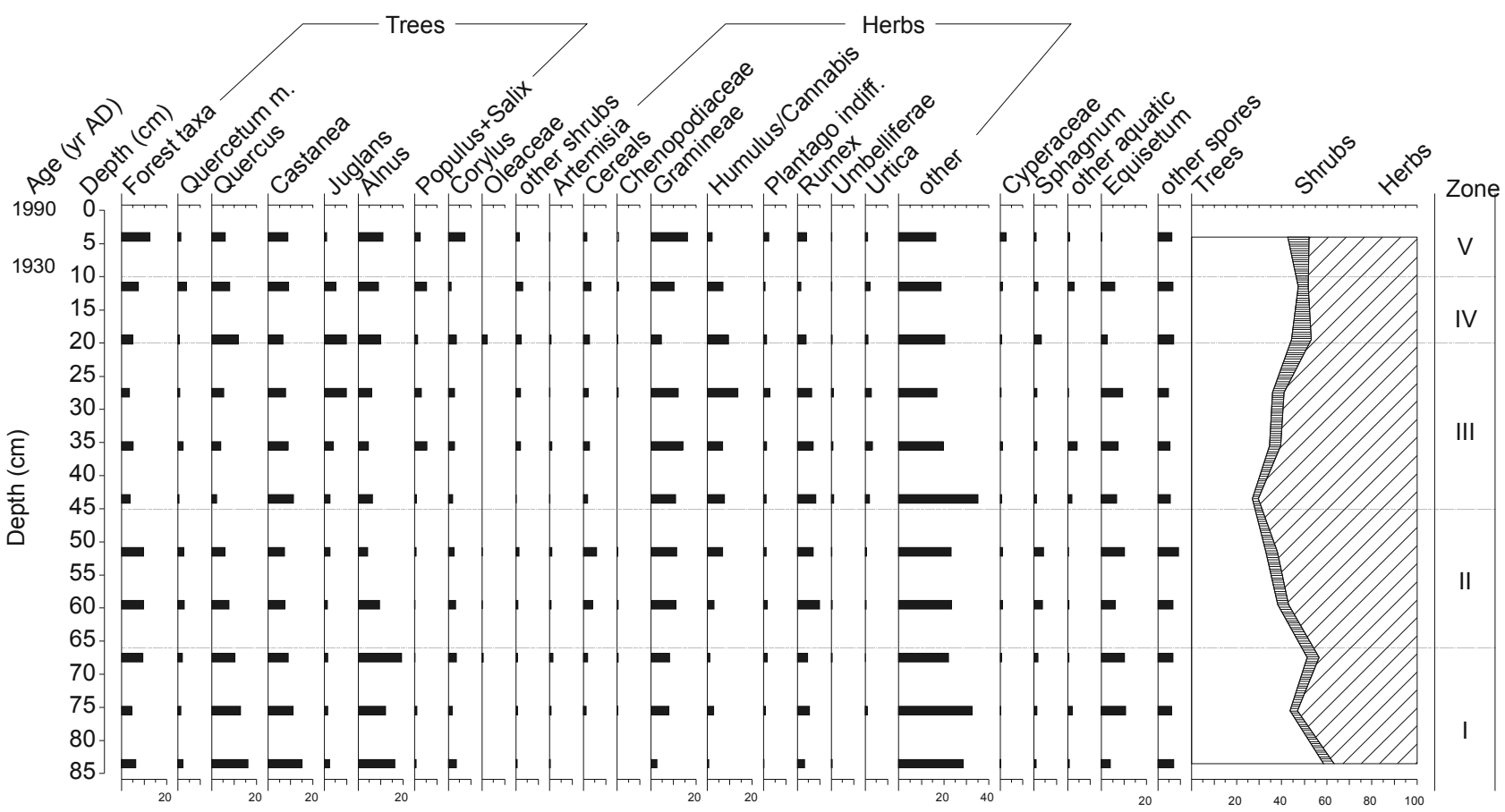

Fig. 8. Percentage pollen diagram (principal taxa only) for the core sequence OR1 from Lake Orta.

Pollen sequence can be broadly subdivided into five biostratigraphic zones (Fig. 8) closely corresponding to those defined by the mineralogy and magnetic susceptibility records.

Zone I $(88-67 \mathrm{~cm})$. This zone shows a slight decreasing trend of the arboreal vegetation without any evidence of agricultural indicators (cereals and ruderals) from the core bottom to around $75 \mathrm{~cm}$. The opening of the canopy should then be natural (dryness, fire) or possibly due to wood exploitation by local population. Therefore, we would expect an increase of the runoff and thus erosion, but the pollen diagram shows that the major decrease is at the expenses of forest taxa and less of the oak wood. This means that the decrease in forest cover should have taken place at middle to high altitudes and the oak forest was still present at low altitude preventing an increase of sediment input to the lake. Above $75 \mathrm{~cm}$ depth, the arboreal percentages, and in particular the forest taxa, increase toward previous values and even higher. The taxa linked to humid environment increase as well suggesting an increase of the precipitation on the area with a possible drowning of some low land and formation of small peat bogs and swampy areas. The drop of some major and minor elements concentrations suggests that the increase of the forest canopy and the presence of aquatic taxa prevented an important sediment contribution to the lake.

Zone II $(67-45 \mathrm{~cm})$. The pollen diagram shows a clear progressive fall of the arboreal taxa mainly at the expenses of Quercus and Alnus. The forest taxa (Betula, Fagus and Pinus) are present up to $50 \mathrm{~cm}$ depth sug- gesting cool and wet climatic conditions. The most interesting feature of this zone is the presence of cereals, showing the highest value ( $\max$ at $c a 50 \mathrm{~cm}$ ). Together with other ruderals, which are indicators of human activity (Compositae, Plantago, Rumex), these features point out the beginning of important agricultural activities in the catchment or an increased effect of the agriculture in the nearby Po Plain probably favoured by suitable climatic conditions. Although the progressive fall of taxa linked to wet environment (Equisetum and Sphagnum) suggests a decrease of precipitation in the area or a destruction of the vegetation along the lake shores, the slightly fall of oak wood suggests a widespread clearance of the drainage area as the main responsible of the crop abandon. The deforestation, however, should have been still the consequence of a new climatic change favouring now a different agricultural activity. In the pollen diagram, in fact, it is possible to observe the beginning of the rise of Juglans frequencies from the end of this zone. Nowadays, all the slopes around the lake are still covered by many walnut and sweet chestnut trees.

Zone III $(45-21 \mathrm{~cm})$. The pollen assemblage reflects the presence of a woody cover characterised by an open canopy with an important presence of Gramineae and Humulus, testifying a remaining human influence on the plant association following the abandonment of cereal crops in favour of arboreal plantations. Poplar, willow, Urtica and part of the aquatics show a slight increase only around $35 \mathrm{~cm}$ suggesting the fast recovery of these wet taxa on the lake shore in advance of the slower woody taxa. Some trees (Quercus, Alnus, Fagus) and 
shrubs (Juniperus, Oleaceae) show an increase in the uppermost part of this interval whereas hop and weeds, Equisetum, Plantago, Rumex show a decrease during the same period. These changes suggest a further recover of woody taxa at the expenses of pioneer and ruderal species.

Zone IV $(21-10 \mathrm{~cm})$. The pollen assemblage reflects a new perturbation of the forest ecosystem: Quercus, Alnus and Juglans, Oleaceae and Corylus all decrease together with Rumex and Humulus. At the same time, the recovery or the increase of many different taxa, among them herbaceous taxa and less-demanding trees, suggest an artificial diversification of the vegetation due to a new clearance of some areas with a consequent opening of the canopy. The modification of the plant cover seems to be mainly directed toward lowland and coastal areas probably caused by an increase of population around the lake shore.

Zone $V(10-0 \mathrm{~cm})$. The high diversity of the vegetational assemblage coupled with low single frequencies suggest the presence of continuous disturbances on the vegetation, probably enhanced by the constant increasing exploitation of the lake shores and slopes by people. The disturbance seems to determine a further increase of erosion and thus of sedimentation rates as also suggested by the increase, at the beginning of this interval, of the concentrations of quartz, plagioclases, k-feldspar and micas and detrital phases such as $\mathrm{K}, \mathrm{Na}$ and $\mathrm{Mg}$.

\section{EFFECT OF POLLUTANTS ON BIOTA}

\subsection{Changes in size and species composition}

Manca \& Comoli (1995) reported results on fossil Cladocera assemblages in a $37 \mathrm{~cm}$ long sediment core collected in 1994 (OR-94) at a station located in the south basin of the lake (Buccione; Fig. 1). Because of the low sedimentation rate almost 400 years were recorded in this core, though this still allows the possibility of a fine resolution ( $1 \mathrm{~cm}$ sediment integrates 5-10 years during the most remote period).

The availability of over 100 years of literature information also allowed the comparison of results on fossil Cladocera with studies on lake fauna and large-scale perturbations. They reveal three phases in the lake's history: an earliest one where the original community was present $\left(17^{\text {th }}\right.$ Century), an intermediate one reflecting eutrophication and acidification, and the most recent one in which the initial recovery was detectable.

The zooplanktonic community before the $19^{\text {th }}$ century indicates a lake with low productivity and low alkalinity. Chydorid species diversity was about 2 (1.86 \pm $0.21)$ and evenness was close to $1(0.91 \pm 0.05)$. Planktonic Cladocera were most represented by Eubosmina longispina and Bosmina longirostris, Daphnia longispina group, and especially Sida crystallina. At that time, in the deep sub-alpine lakes of Italy and Switzerland, S. crystallina developed truly pelagic populations, of a morphotype having the adhesive gland atrophic (var. limnetica; Hutchinson 1967; Margaritora 1983), and able to live down to $150 \mathrm{~m}$ depth (Baldi et al. 1953).

A series of events affected the Cladocera community. Apart from the earliest changes (probably driven by changes in temperature, see below), the first event to modify the original community of the lake is detected during the period in which exotic fish (landlocked shad, Alosa phallax nilotica) were introduced into the lake, accomplished in 1880 (De Agostini 1897). The total number of remains increased, and of the two subgenera of Bosmina present before, only Eubosmina was left for a while. This has been interpreted as a result of the positive selection of Bosmina over Eubosmina by the Alosa phallax lacustri (or nilotica [?]), because of its habit of preying in the upper $20 \mathrm{~m}$, as observed in Lake Maggiore (Berg \& Grimaldi 1966). Eubosmina is in fact usually found in deeper waters (Margaritora 1983).

There was a good correspondence between the planktonic Cladocera community described in 1879 by Pavesi and the assemblage reconstructed from the remains found in the core sections at this level. Both the longispina and the pulex groups were present within the nominate subgenus of the Daphnia genus. Although only Bosmina longirostris was reported by Pavesi (1896), in the sediments Eubosmina was in general more abundant than Bosmina.

The phase of severe pollution (1928-1960) is first detected in the core as a dramatic decrease in the Shannon diversity index and in the number of species of Cladocera: Chydorus sphaericus, initially with some Alona are the only taxa left at this level of the core. The decrease in the pelagic/littoral ratio, down to $20 \%$, indicate that planktonic species were more affected than the littoral ones. Total concentration of remains also decreased dramatically with pollution (Manca \& Comoli 1995). The drastic changes in the zooplankton community was also followed, with a delay of some years, by the disappearance from the sediments of cocoons belonging to the oligochaete Spirosperma ferox (Bonacina et al. 1986).

The earliest sign of improved conditions in Lake Orta may be the increased accumulation of organic matter in sediments between 1951 and 1962. An increase in Cladocera remains has been detected only from 1962, after the initial recolonisation by phytoplankton. Vollenweider (1963) described the lake in the period 1958-1961 as highly unstable, with rapid recolonisation by various phytoplankton species, which attained high values of total biomass. No Cladocera were found in the pelagic zone. Due to the tremendous increase in ammonium concentration and the high estimates of primary production, he argued that the lake was undergoing a process of acidification and eutrophication. Indeed, fossil pigments of this period show variable but generally high accumulation rates with the presence of Oscillatoria sp. (Figs 6, 7). 
The sediment core indicates that Chydorus sphaericus is the dominant species during the recolonisation phase. Although being typically littoral, at the beginning of the 1980s it developed a truly pelagic population in the lake (Bonacina \& Bonomi 1984), thus suggesting the presence of abundant filamentous algae and blooms of blue-greens in the pelagic zone (Hutchinson 1967). This species is known for its ability to become planktonic, in lakes rich in filamentous algae, which are used as a feeding substrate by the animals (Frey 1968).

The recolonisation of the lake by truly pelagic species is also detected in the core, with a rise of the $\mathrm{P} / \mathrm{L}$ ratio above $50 \%$, and a decrease in chydorids. The general increase in the number of remains of the uppermost $6 \mathrm{~cm}$ of the core also reflects an increase in their accumulation rate.

\subsection{Effects of metal contamination on diatoms}

Lake Orta has also provided an opportunity to study impact of metals pollution on diatom assemblages. Ruggiu et al. (1998), in a palaeolimnological study described the acute and long-term effects of $\mathrm{Cu}$ contamination on the diatom community of the lake, at a water concentration of about $80 \mu \mathrm{g} \mathrm{l}^{-1}$. They documented the progressive impoverishment of the diatom community of the lake, which was originally similar to that of the other deep, subalpine lakes. Fragilaria crotonensis, Asterionella formosa, Cyclotella bodanica and C. stelligera were quickly extirpated by pollution and never reappeared. Species like Synedra tenera were more resistant to pollution, and reacted with an increase in the teratological forms, already present in the lake, at very low percentages. This observation confirmed the link between diatom teratogeny and metal pollution (Yang \& Duthie 1993; McFarland et al. 1997). During pollution, Achnanthes minutissima, "the most important diatom species both in the sediment and the plankton of the lake" (van Dam \& Mertens 1990) is positively selected, confirming its tolerance to high levels of metals, copper included (Takamura et al. 1989; van Dam \& Mertens 1990).

\subsection{Changes in the size structure of communities at different trophic and phyletic levels}

Cattaneo et al. (1998) applied a size-based approach (Peters 1993) to the analysis of the fossil remains of Lake Orta in the same core (OR-94) used by Manca \& Comoli (1995), following the size distribution of diatoms, thecamoebians, and cladocerans of about 300 years before the onset of pollution to 60 years afterwards. They interpreted Lake Orta pollution as a stress in the sense of Odum (1985), who theorized the dominance of small, rapidly reproducing organisms, in stressed ecosystems. The reduction of average size in the three communities at different phyletic and trophic levels, as well as the selection of smaller morphotypes within a taxon, is interpreted as a validation of the hy- pothesized link between stress and size. Since planktivorous and piscivorous fish were both practically absent, the success of smaller organisms following the onset of pollution could not be explained by selective predation, but was likely to depend on the increased resistance of smaller organisms to contaminants. The toxic doses of many contaminants decline with size (Chappell 1992), and perhaps the longer generation time and lower clearance rates of larger organisms (Fenchel 1974) expose them to effectively higher levels of pollutants, resulting in greater mortality. Previously, the link between size and stress had been demonstrated only in short term, laboratory tests. Lake Orta has provided a unique case to study the response to a chronic pollution that lasted over 50 years.

\section{EFFECT OF CLIMATE CHANGE}

A study of the remains of different type of organisms in the $37 \mathrm{~cm}$ long core OR 94 revealed that an important environmental change occurred in the second half of the $17^{\text {th }}$ century. Changes in size and species composition of thecamoebians were indicative of a decrease in water temperature (Asioli \& Medioli 1994). The concomitant decrease in concentration and accumulation rate of Cladocera, with a shift toward littoral species (decrease in Planktonic/Littoral species) was also regarded as indicative of a decrease in water level driven by a decrease in temperature (Manca \& Comoli 1995). Changes in habitat diversity at stable water levels can conceivably bring about the same changes (Frey 1986) and changes in the $\mathrm{P} / \mathrm{L}$ ratio can result from a differential response of the planktonic and littoral Cladocera to changing primary production, with planktonic forms favoured when productivity increases (Crisman \& Whitehead 1978). Indeed, decreases in total abundance and accumulation rate of remains are generally interpreted as indicating lower temperatures, since animals moult and reproduce less when cold (Frey 1986). However, a $1 \mathrm{~m}$ core taken from the deepest area showed that during the $17^{\text {th }}$ Century there was a significant decrease of $\mathrm{SiO}_{2}, \mathrm{~S}, \mathrm{P}$, and generally lower concentrations of algal pigments (Figs 6,7) compared with those recorded for the $18^{\text {th }}$ and $19^{\text {th }}$ centuries.

Palaeoclimatic studies do show a general decline in temperature of $1^{\circ} \mathrm{C}$ world wide during the time of these changes in the community structure in Lake Orta (16501675), a period known as "Maunder's minimum" (Lamb 1977; Eddy 1976).

\section{CONCLUSIONS AND FUTURE RESEARCH NEEDS}

It has been shown by the above chapters that a number of palaeolimnological studies were carried out during the past $10-15$ years and how the results served to integrate the existing data and to add new information on the long-term limnological record of this lake case study. The gradual enormous loading of copper and 
ammonium salts has had a profound effect on the limnological history of Lake Orta. The chief consequence of the pollution was a nitrate and ammonia accumulation, a striking lowering of the $\mathrm{pH}$ and an increased oxygen hypolimnetic deficit. The manifestation of this in the sediments has been initially a general marked decrease or even a complete disappearance of the invertebrate organisms and diatoms, an increase of pigments (and LOI) due to senescent or dead algae accumulation, and subsequently a strong modification in their taxonomic composition and assemblages. However, the pro??cess has been neither regular nor progressive: there have evidently been several large fluctuations in productivity and organism biomass. Deep changes in the reduction of average body size in three communities (diatoms, thecamoebians, and cladocerans), and the presence of teratological frustules of Synedra tenera during the 50 years of pollution, were also reported. In 1989-1990 the lake was treated with lime and it rapidly recovered. Unfortunately, even the most recent studies (Manca \& Comoli 1995; Cattaneo et al. 1998; Ruggiu et al. 1998), were made on cores collected in 1994 and the core sectioning adopted (usually $1 \mathrm{~cm}$, corresponding to 3-5 or more years; cf. Tab. 3) had not a sufficient resolution for studying in detail the sub-fossil remains in relation to the lake recovery by liming. Future high resolution sediment core studies (possibly at annual resolution) should be addressed in the direction of consider this large impact event not only or as much to monitor the biota development and recovery as to compare and "calibrate" these sediment data with the well documented last 12 years of limnological information.

As regards the "natural variability", climatic changes during recent centuries (e.g. the Little Ice Age) only agree in a very general way with primary production rates. Changes in Cladocera density, size and composition, and pigments concentrations appear to occur before climatic or anthropogenic changes are indicated by the pollen record. Thus, changes in the pollen composition appear to be a very conservative indicator of climate change. Also in this case, however, without a finer resolution study around the main biological and geochemical changes in the cores it is difficult to determine the exact sequence of events associate with natural impacts.

\section{ACKNOWLEDGMENTS}

We would like to thanks F. Oldfield and M. Frignani for helping in the field and for making available the mini-Mackereth corer during the 1990 campaign.

\section{REFERENCES}

Adams, M.S., P. Guilizzoni \& S. Adams. 1978. Sedimentary pigments and recent primary productivity in Northern Italian lakes. Mem. Ist. ital. Idrobiol., 36: 276-285.

Alvisi, F. 1993. Ricostruzione paleoambientale dei laghi sudalpini Orta, Varese, Mergozzo e Ganna attaverso un'analisi multidisciplinare dei sedimenti olocenici e attuali. Tesi di Dottorato in Scienze della Terra, Dip. Scienze Geologiche, Università di Bologna: 83 pp.

Alvisi, F., P.G. Appleby, A. Asioli, M. Frignani, F. Oldfield, M. Ravaglioli \& L. Vigliotti. 1996. Recent environmental changes as recorded by the sediments of Lake Orta (Northern Italy). In: Piccione V. C. Antonelli \& A. Guerrini (Eds), Atti del $3^{\circ}$ Workshop Progetto Strategico Clima Ambiente e Territorio nel Mezzogiorno. Potenza, 26-29 Novembre 1990. CNR: 243-256.

Ambrosetti, W., L. Barbanti, R. de Bernardi, V. Libera \& A. Rolla. 1994. La piena nel Lago Maggiore nell'autunno 1993 un evento di portata secolare. Documenta Ist. ital. Idrobiol., 45: $51 \mathrm{pp}$.

Appleby, P.G. \& F. Oldfield. 1978. The calculation of ${ }^{210} \mathrm{~Pb}$ dates assuming a constant rate of supply of unsupported ${ }^{210} \mathrm{~Pb}$ to the sediment. Catena, 5: 1-8.

Appleby, P.G., N. Richardson \& P.J. Nolan. 1991. ${ }^{241}$ Am dating of lake sediments. Hydrobiologia, 214: 35-42.

Appleby, P.G., N. Richardson \& P.J. Nolan. 1992. Self-absorption corrections for well-type germanium detectors. Nucl. Instr. Methods B, 71: 228-233.

Appleby, P.G., P.J. Nolan, D.W. Gifford, M.J. Godfrey, F. Olfield, N.J. Anderson, \& R.W. Battarbee. $1986 .{ }^{210} \mathrm{~Pb}$ dating by low-background gamma counting. Hydrobiologia, 143 : 21-27.

Asioli, A. \& F.S. Medioli. 1994. Ricostruzione dei paleoambienti attraverso le tecamebe in alcuni laghi sudalpini (Orta, Varese e Candia). Atti del $10^{\circ}$ Congresso A.I.O.L.: 487501.

Baldi, E., V. Tonolli \& L. Tonolli Pirocchi. 1953. La differente evoluzione di due laghi già costituenti un unico bacino: il Lago Maggiore e il Lago di Mergozzo. Mem. Ist. ital. Idrobiol., 7: 49-107.

Baudo, R., L. Amantini, F. Bo, R. Cenci, P. Hannaert, A. Lattanzio, G. Marengo \& H. Muntau. 1989. Spatial distribution patterns of metals in the surface sediments of Lake Orta (Italy). Science Total Environ., 87/88: 117-128.

Baudo, R. \& M. Beltrami. 2001. Chemical composition of Lake Orta sediments. J. Limnol., 60(2): 213-236.

Berg, A. \& E. Grimaldi. 1966. Ecological relationships between planktophagic fish species in the Lago Maggiore. Verh. int. Ver. Limnol., 16: 1065-1073.

Bonacina, C. \& G. Bonomi. 1984. I grandiosi effetti ambientali determinati dalle prime fasi del disinquinamento del Lago d'Orta. Documenta Ist. ital. Idrobiol., 2: 24 pp.

Bonacina, C., G. Bonomi \& C. Monti. 1986. Oligochaete cocoon remains as evidence of past lake pollution. Hydrobiologia, 143: 395-400.

Bonacina, C., A. Calderoni \& R. de Bernardi (Eds). 1990. Ricerche limnologiche sul Lago d'Orta finalizzate al suo recupero. Documenta Ist. ital. Idrobiol., 28: $131 \mathrm{pp}$.

Calderoni, A. \& R. Mosello. 1990. Evoluzione delle caratteristiche chimiche del Lago d'Orta nel quadriennio Febbraio 1984 - Febbraio 1988. Documenta Ist. ital. Idrobiol., 28: 71-87.

Calderoni, A., Mosello R \& A. Quirci. 1991. Chemical response of Lake Orta (Northern Italy) to liming. Arch. Hydrbiol., 122: 421-439.

Calderoni, A. \& G.A. Tartari. 2001. Evolution of the water chemistry of Lake Orta after liming. J. Limnol., 60(1): 6978.

Cattaneo, A. 1992. The anthropogenically stressed periphyton of Lake Orta, Italy. Hydrobiologia, 234: 111-121.

Chamley, H. (Ed.). 1989. Clay sedimentology. SpringerVerlag, Berlin: 425-455.

Chappell, W.R. 1992. Scaling toxicity data across species. Environ. Geochem. Health, 14: 71-80.

Cattaneo, A., A. Asioli, P. Comoli \& M. Manca. 1998. Organisms response in a chronically polluted lake 
supports hypothesized link between stress and size. Limnol. Oceanogr., 43: 1938-1943.

Corbella, C., V. Tonolli \& L. Tonolli. 1958. I sedimenti del Lago d'Orta, testimoni di una disastrosa polluzione cuproammoniacale. Mem. Ist. ital. Idrobiol., 10: 9-50.

Crisman, T.L. \& D.R. Whitehead. 1978. Paleolimnological studies on small New England (U.S.A.) ponds. Part II. Cladoceran community responses to trophic oscillations. Pol. Arch. Hydrobiol., 25: 75-86.

De Agostini, G. 1897. Il Lago d'Orta. Carlo Clausen, Torino: $39 \mathrm{pp}$.

Eddy, J.A. 1976. The Maunder Minimum. Science, 192: 11891202 .

Engstrom, D.R. \& H.E. Jr. Whright. 1984. Chemical stratigraphy of lake sediments as a record of environmental change. In: E.Y. Haworth \& J.W.G. Lund (Eds), Lake sediments and Environmental history. Leicester University Press: 11-67.

Engstrom D.R., E.B. Swain \& C. Kingston. 1985. A palaeolimnological record of human disturbance from Harvey's lake, Vermont: geochemistry, pigments and diatoms. Freshwat. Biol., 15: 261-288.

Faegri, K. \& J. Iversen. 1964. Textbook of pollen analysis. J. Wiley \& Sons, London, 4th Edition: 324 pp.

Fenchel, T. 1974. Intrinsic rate of natural increase: the relationship with body size. Oecologia, 14: 317-326.

Frey, D.G. 1986. Cladocera analysis. In: B.E. Berglund (Ed.), Handbook of Holocene Palaeoecology and Palaeohydrobiology. John Wiley \& Sons: 667-692.

Frignani, M., P. Guilizzoni, A. Lami, F. Oldfield \& M Ravaioli. 1995. Suitability of recent sediments from four northern Italian lakes for palaeoenvironmental research some preliminary results. In: Piccione V. \& C. Antonelli $\&$ A. Guerrini (Eds), Atti del $3^{\circ}$ Workshop Progetto Strategico Clima Ambiente e Territorio nel Mezzogiorno, Potenza, 26-29 Novembre 1990. CNR: 703-727.

Grimm, E.C. 1991. TILIA software package. Illinois State Museum, Springfield, USA.

Guilizzoni, P., G. Bonomi, G. Galanti \& D. Ruggiu. 1982. Basic trophic status and recent development of some Italian lakes as revealed by plant pigments and other chemical components in sediment cores. Mem. Ist. ital. Idrobiol., 40: 79-98.

Guilizzoni, P., G. Bonomi, G. Galanti \& D. Ruggiu. 1983. Relationship between sedimentary pigments and primary production: evidence from core analyses of twelve Italian lakes. Hydrobiologia, 103: 103-106.

Guilizzoni, P. \& A. Lami. 1988. Sub-fossil pigments as a guide to the phytoplankton history of the acidified Lake Orta (N. Italy). Verh. int. Ver. Limnol., 23: 874-879.

Guilizzoni, P. \& A. Lami. 1990. Ricerche paleolimnologiche sul Lago d'Orta. Documenta Ist. ital. Idrobiol., 28: 53-69.

Guilizzoni, P. \& A. Lami. 1992. Historical records of changes in the chemistry and biology of Italian lakes. Mem. Ist. ital. Idrobiol., 50: 61-77.

Hutchinson, J.E. 1967. A treatise on limnology. Vol. II. John Wiley \& Sons: $1115 \mathrm{pp}$.

Lamb, H.H. 1977. Climate. Past, present and future. Methuen \& C., London, Vol. 2: $835 \mathrm{pp}$

Leavitt, P.R. 1993. A review of factors that regulate carotenoid and chlorophyll deposition and fossil pigment abundance. J. Paleolimnol., 19: 109-127.

Mackereth, F.J.H. 1996. Some chemical observations on postglacial lake sediments. Philos. Trans. of the Royal Soc. London B, 250: 165-213.

Manca, M. \& P. Comoli. 1995. Temporal variations of fossil Cladocera in the sediments of Lake Orta (N. Italy) over the last 400 years. J. Paleolimnol., 14: 113-122.
Margaritora, F. 1983. Cladoceri. C.N.R. Collana Progetto Finalizzato "Promozione della qualità dell'ambiente". Guide per il riconoscimento delle specie animali delle acque interne italiane: $169 \mathrm{pp}$.

McFarland, B.H., B.H. Hill \& W.T. Willingtom. 1997. Abnormal Fragilaria in streams impacted by mine drainage. J. Freswat. Ecol., 12: 141-149.

Mitchell, M.J., J.S. Owen \& S.C. Schindler. 1990. Factors affecting sulfur incorporation into lake sediments: paleoecological implications. J. Paleolimnol., 4: 1-22.

Monti, R. 1930. La graduale estinzione della vita nel Lago d'Orta. Rend. R. Ist. Lomb. Sc. Lett., 63: 3-22.

Moore, P.D. \& J.A. Webb. 1978. An illustrated guide to pollen analysis. Hodder \& Stoughton, London.

Odum, E.P. 1985. Trends expected in stressed ecosystems. BioScience, 35: 419-422.

Pavesi, P. 1879. Nuove serie di ricerche sulla fauna pelagica dei laghi italiani. Rend. R. Ist. Lomb. Sc. Lett., 12: 474483.

Pavesi, P. 1896. La distribuzione dei pesci in Lombardia. In: G. De Agostini, 1897. Il Lago d'Orta. Carlo Clausen, Torino: $39 \mathrm{pp}$.

Peters, R.H. 1993. The implications of body size. Cambridge University Press, Cambridge.

Provini, A. \& F. Gaggino. 1985. Sediment as a record of copper pollution in Lake Orta. Verh. int. Ver. Limnol., 22: 2390-2393.

Rossi, D., R. Baudo, M. Beltrami, M. Contesini \& A. Pranzo. 1998. Valutazione della tossicità dei sedimenti del Lago d'Orta mediante esposizione di organismi in situ e test di laboratorio. Acqua Aria, Giugno/Luglio 1998: 105-115.

Ruggiu, D., A. Luglié, A. Cattaneo \& P. Panzani. 1998. Paleoecological evidence for diatom response to metal pollution in Lake Orta (N. Italy). J. Paleolimnol., 20: 333345.

Sanger, J.E. 1988. Fossil pigments in paleoecology and paleolimnology. Palaeogeography, Palaeoclimatology, Palaeoecology, 62: 343-359

Sanger, J.E. \& E. Gorham. 1972. Stratigraphy of fossil pigments as a guide to the post-glacial history of Kirchner Marsh, Minnesota. Limnol. Oceanogr., 17: 840-854.

Swain, E.B. 1985. Measurement and interpretation of sedimentary pigments. Freshwat. Biol., 15: 53-75.

Takamaura, N., F. Kasai \& M.M. Watanabe. 1989. Effects of $\mathrm{Cu}, \mathrm{Cd}$ and $\mathrm{Zn}$ on photosynthesis of freshwater benthic algae. J. Appl. Phycol., 1: 39-52.

Takamura, N., S. Hatakeyama \& Y. Sugaya. 1990. Seasonal changes in species composition and production of periphyton in an urban river running through an abandoned copper mining region. Japan. J. Limnol., 51: 225-235.

Tucker, M.E. (Ed.). 1988. Techniques in sedimentology. Blackwell Scientific Publication, Oxford: 394 pp.

Van Dam, H. \& A. Mertens. 1990. A comparison of recent epilithic diatom assemblages from the industrially acidified and copper polluted Lake Orta (Northern Italy) with old literature data. Diatom Res., 5: 1-13.

Vollenweider, R.A. 1963. Studi sulla situazione attuale del regime chimico e biologico del Lago d'Orta. Mem. Ist. ital. Idrobiol., 16: 21-125.

Yang, J.R. \& H.C. Duthie. 1993. Morphology and ultrastructure or teratological forms of the diatoms Stephanodiscus niagarae and S. parvus from Hamilton Harbour (Lake Ontario, Canada). Hydrobiologia, 269/270: $57-66$. 